trans-Dibenzoylethylene ans-Di-p-toluylethylene cis-Di-p-toluylethylene cis-Di- $p$-toluylethylene cis-Di( $p$-chlorobenzoyl)-ethylene cis-Di( $p$-chlorobenzoyl)-ethylene cis-Di( $p$-bromobenzoyl)-ethylene

Reduction product and
yield
Diphenacyl
Diphenacyl
4 : 4'-Dimethyldiphenacyl
4 : 4'-Dimethyldiphenacyl
4 : 4'-Dichlorodiphenacyl
4 : 4'-Dichlorodiphenacyl
4 : 4'-Dibromodiphenacyl
4 : 4'-Dibromodiphenacyl

per 70 75 95 80 90 90

It is noteworthy that the cis-compounds react more rapidly with this reducing agent. With the transisomers some unchanged substance was always found in the product.

NeIL CampbetL

Nandoomal Khanna

Department of Chemistry,

University of Edinburgh. Sept. 17.

${ }^{1}$ Conant, J. B., and Lutz, R. E., J. Amer. Chem. Soc., 45, 1047 (1923) ; Lutz, R. E., ibid., 51, 3008 (1929); Lutz, R. E., and Palmer. F. S., ibid., 57, 1947, 1953, 1957 (1935).

2 Lutz, R. E., and Reveley, W. G., J. Amer. Chem. Soc., 61, 1854 (1939).

Allen, C. F. H., and Blatt, A. H., Gilman's “Organic Chemistry", $1,603(1938)$.

\section{Total Conjugation of Linoleic Acid in Oxidation with Lipoxidase}

Bolland and Koch ${ }^{1}$ postulated the mechanism of autoxidation of linoleate to be:.

$$
\begin{aligned}
& -\mathrm{CH}_{2} \cdot \mathrm{CH}: \mathrm{CH} \cdot \mathrm{CH}_{2} \cdot \mathrm{CH}: \mathrm{CH} \cdot \mathrm{CH}_{2}- \\
& \text { (13) (12) (11) (10) (9) } \\
& \left\{\begin{array}{l}
-\mathrm{CH}_{2} \cdot \mathrm{CH}: \mathrm{CH} . \mathrm{CH} \cdot \mathrm{CH}: \mathrm{CH} \cdot \mathrm{CH}_{2}- \\
-\mathrm{CH}_{2} \cdot \mathrm{CH}: \mathrm{CH} . \mathrm{CH}: \mathrm{CH} . \stackrel{\mathrm{CH}}{\mathrm{CH}} \cdot \mathrm{CH}_{2}-
\end{array}\right\} \text { (III) }-\frac{+\mathrm{O}_{2}}{+\mathrm{H}^{*}} \rightarrow \\
& \left(-\mathrm{CH}_{2} \cdot \stackrel{\text { CH}}{\mathrm{C}} \mathrm{CH}: \mathrm{CH} . \mathrm{CH}: \mathrm{CH}^{-\mathrm{CH}_{2}-}\right. \text { (IV) } \\
& -\mathrm{CH}_{2} \cdot \mathrm{CH}: \mathrm{CH} . \mathrm{CH} . \mathrm{CH}: \mathrm{CH} \cdot \mathrm{CH}_{2}- \\
& \text { OOH } \\
& -\mathrm{CH}_{2} \cdot \mathrm{CH}: \mathrm{CH} . \mathrm{CH}: \mathrm{CH} . \mathrm{CH} . \mathrm{CH}_{2}- \\
& -\mathrm{CH}_{2} \cdot \mathrm{CH} . \mathrm{CH}: \mathrm{CH} . \mathrm{CH}: \mathrm{CH} . \mathrm{CH}_{2}- \\
& \text { OOH }
\end{aligned}
$$

From the ultra-violet absorption due to the conjugation of the double bonds and from the active hydrogen content of the resulting mixture of peroxidic products, they concluded that it consisted of approximately equal parts of the hydroperoxides V, VI and VII, indicating that the free radical structures II, III and IV contribute equally to the free radical resonance hybrid.

Other workers' results are in agreement with the general outlines of the mechanism ${ }^{2,3}$. In the hydrogenated products, Bergström ${ }^{2}$ identified comparable amounts of 9 - and 13-hydroxystearate, but was unable to detect the 11-isomer.

The oxidation of linoleates in aqueous solution with crude soya-bean lipoxidase seems to follow the same general course as the autoxidation ${ }^{2,3}$. It was observed that the extinction at $234 \mathrm{~m} \mu$ per absorbed oxygen increased when the enzyme was purified.

When crystalline lipoxidase ${ }^{5}$ became available, the problem was reinvestigated under conditions least likely to promote side reactions or decompositions. The oxidations were carried out in Warburg vessels under air, using sodium linoleate substrate ${ }^{4}$. The reactions were stopped by addition of alcohol, and light absorption was measured using the Beckman spectrophotometer.

Apparent molar extinction coefficients of the primary oxidation product at $234 \mathrm{~m} \mu$ were found to be 23,000 at $37^{\circ}, 27,800$ at $8^{\circ}$ and 31,400 at $0^{\circ}$, indicating that reaction temperature affects the formation or decomposition of conjugated diene to a marked degree. Reduction of the extinction by elevated temperature is accompanied by increased absorption at $270 \mathrm{~m} \mu$. The extinction coefficient at $234 \mathrm{~m} \mu$ remains near 30,000 up to 30 per cent oxidation at $0^{\circ}$, whereas at $37^{\circ}$ it has decreased to 20,000 at 10 per cent oxidation.

Thus in the rapid enzymatic oxidation of linoleate at low temperature, one pair of conjugated double. bonds is formed for every oxygen absorbed. This indicates that III and IV are the main contributing structures to the free radical resonance hybrid, resulting in oxygen addition at the ends of the resonating system, giving only the conjugated hydroperoxides VI and VIr. Variable amounts of products, other than conjugated hydroperoxides, formed at higher temperatures, with longer reaction times, or with impure enzyme, appear to be attributable to decompositions or secondary oxidations of conjugated peroxides.

Our evidence suggests that a similar mechanism may account for the low extinction coefficients observed in the autoxidation of linoleates.

A full report will appear in due course (Arch. Biochem.).

Dept. of Physiological Chemistry,

Sune Bergström University of Lund.

RaLPH T. HoLmaN

(National Research Council Fellow)

Department of Biochemistry, Medical Nobel Institute, Stockholm.

${ }^{1}$ Bolland and Koch, J. Chem. Soc, 445 (1945).

'Bergström, Nature, 156, 717 (1945); Arkiv Kemi, Min.-Geol., 21, A, $14,15(1945)$.

- Holman, Arch. Biochem., 10, 519 (1946).

- Theorell, Bergström and Akesson, Pharm. Acta Helv., 21, 318 (1946).

$s$ Theorell, Holman and Åkesson, Arch. Biochem., 14, 250 (1947).

\section{Ammonium Salts of Sulphanilamides and Sulphonic Acids}

SulPHANILAMide salts of a few sulphonic and carboxylic acids have been described ${ }^{1,2,3}$, but they have not been isolated in pure form and characterized. In the course of our work on surface-active com. pounds, and with the object of examining their activity as intestinal bacteriostatic agents, we have prepared sulphanilamide salts of diisopropyl naph. thalene sodium sulphonate (m.p. 220-22 $2^{\circ}$, sodium dioctylsulphosuccinate, and lauryl-p-toluidide-2sodium sulphonate. Suitable experimental conditions were first determined by the preparation of $(a)$ salts of naphthalene- $\beta$-sulphonic acid and sulphanilamide (m.p. 263-64 ${ }^{\circ}$ ), sulphathiazole $\left(214-15^{\circ}\right)$, sulphapyridine $\left(152-53^{\circ}\right)$, sulphadiazine $\left(188^{\circ}\right)$, sulphamerazine $\left(118-120^{\circ}\right)$, sulphaguanidine $\left(225-26^{\circ}\right), \mathrm{N}^{1}$. acetylsulphanilamide $\left(254-55^{\circ}\right)$, and $p$-aminobenzoic acid (decomp. above $260^{\circ}$ ); and $(b)$ sulphanilamide salt of phenol-p-sulphonic acid (241-42 decomp.). The last salt, described earlier ${ }^{1}$ as giving m.p. 216-220 (decomp.), was apparently a mixture containing sulphanilamide hydrochloride. 